\title{
Aplikasi Pembelajaran Matematika Kelas III SD Berbasis Android
}

\author{
Irwan $\operatorname{Karim}^{\left.1^{*}\right)}$ \\ Andi Mariani2 $\left.{ }^{*}\right)$ \\ Program Studi Teknik Informatika, Politeknik Gorontalo \\ email : irwankarim@poligon.ac.id \\ email : andimariani@poligon.ac.id
}

\begin{abstract}
Matematika merupakan pelajaran wajib bagi seluruh kalangan siswa khususnya Sekolah Dasar untuk melatih berpikir logis, analistis, sistematis dan kritis. Proses pembelajaran matematika dalam skala kompetensi kelas III SD, dibutuhkan metode yang tepat untuk dapat menyelesaikan masalah anak yang malas belajar dikarenakan metode pembelajaran dirumah masih menggunakan buku diktat dan anak cenderung hanya suka bermain. Implementasi dari penjabaran diatas dituangkan kedalam teknologi berbasis Android sebagai media pendukung proses belajar anak dimanapun dan kapanpun, dengan variasi tampilan yang menarik dan interaktif. Sehingga anak tidak mudah bosan belajar dan dapat lebih mudah memahami dan mengerti dalam belajar matematika dengan bimbingan orang tua dirumah.
\end{abstract}

Kata kunci-Matematika, Kelas III SD, Android

\section{PENDAHULUAN}

Salah satu mata pelajaran yang termasuk didalam kurikulum pendidikan di Indonesia mulai dari tingkatan Sekolah Dasar, Sekolah Menengah dan Perguruan Tinggi adalah pelajaran matematika. Pelajaran matematika diberikan dalam ruang lingkup Sekolah Dasar dan Madrasah Ibtidaiyah khususnya kelas III untuk melatih siswa berpikir sistematis (teratur), logis (masuk akal), kritis (banyak bertanya dan tak lekas percaya), kreatif dan konsisten.

Konsep dalam pembelajaran matematika bersifat abstrak. Artinya pembelajaran matematika menitik beratkan kepada siswa untuk berpikir cepat dan menghasilkan hasil yang tepat dengan menanamkan konsep-konsep dasar materi. Sedangkan pada umumnya siswa SD berpikir dari hal-hal yang konkret menuju hal-hal yang abstrak. Sehingga hal ini menyebabkan siswa menganggap bahwa pembelajaran matematika adalah pembelajaran yang paling sulit.

Kenyataan di lapangan membuktikan bahwa siswa mengalami kendala di dalam kelas yaitu daya tangkap siswa terhadap mata pelajaran matematika kurang maksimal. Sehingga berpengaruh pada prestasi akademik siswa tersebut. Kendala lain dari siswa tersebut yaitu ada beberapa aplikasi yang sudah digunakan dalam proses pembelajaran belum maksimal dikarenakan masih terdapat kekurangan. Sehingga banyak siswa kurang fokus dan cenderung bermain disaat proses belajar dibandingkan memperhatikan guru yang sedang mengajar. Oleh karena itu penulis mencoba membangun sebuah aplikasi pembelajaran matematika untuk kelas III SD.

\author{
Muhammad Rizqi Tohopi ${ }^{3)}$ \\ Program Studi Teknik Informatika, Politeknik Gorontalo \\ email : rizqitohopi@smart-ti.com
}

Pendekatan pembelajaran matematika yang sebaiknya diterapkan yaitu disesuaikan dengan perkembangan zaman dengan memberikan kesempatan kepada siswa untuk mengeluarkan pengetahuannya sendiri dalam memahami konsep-konsep yang diajarkan dan mengkomunikasikan ideidenya dalam bentuk konkret salah satunya melalui metode pembelajaran berbasis teknologi informasi menggunakan smartphone. Saat ini smartphone difasilitasi dengan sistem operasi Android yang bersifat open source sehingga memudahkan developer untuk menuangkan idenya dalam pemenuhan kebutuhan publik. Smartphone juga bersifat moveable (mudah dibawa kemana-mana) yang bertujuan membantu para orang tua untuk mengajak anak belajar dimanapun dan kapanpun.

Aplikasi pembelajaran matematika berbasis android ini dirancang dengan terfokus pada variasi tampilan yang menarik dan interaktif. Sehingga dapat manarik perhatian dan minat belajar siswa untuk belajar matematika.

\section{METODE PENELITIAN}

Pada bagian ini menjelaskan mengenai gambaran umum pada Aplikasi Media Pembelajaran Untuk PAUD Berbasis Android.

\subsection{Skema Sistem Yang Berjalan}

\subsubsection{Skema Sistem Yang Berjalan di Sekolah}

Skema sistem yang berjalan di sekolah dapat dilihat pada gambar 2.1

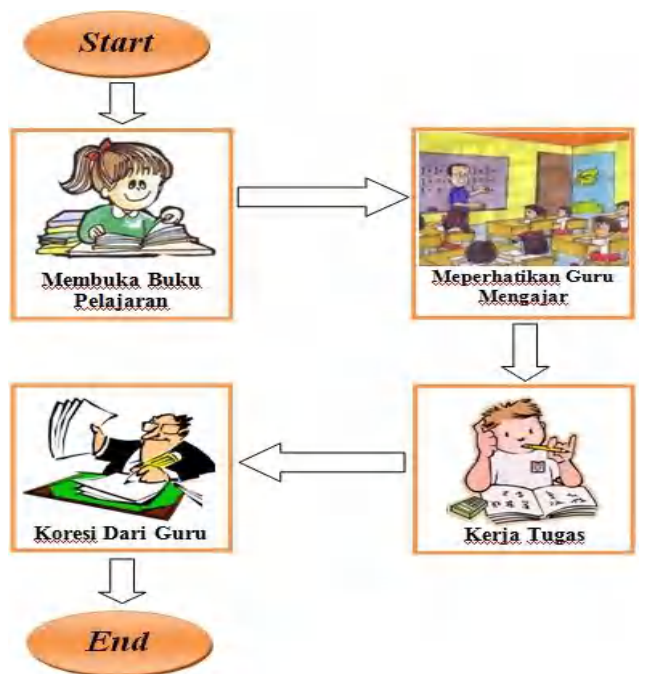

Gambar 2.1 Skema sistem yang berjalan a1 sekolah 


\subsection{Perancangan Sistem}

\subsubsection{Use Case Diagram yang diusulkan}

Use case merupakan gambaran skenario dari interaksi pengguna dengan sistem. Sebuah diagram use case menggambarkan hubungan antara aktor dan kegiatan yang dapat dilakukannya terhadap aplikasi.

Use Case Diagram yang diusulkan, dapat dilihat pada gambar 2.2.

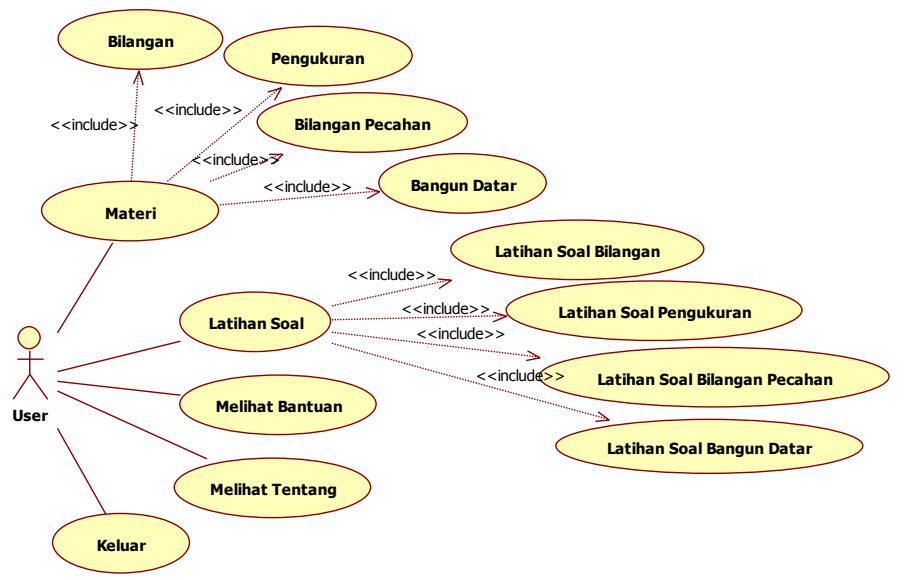

Gambar 2.2 Use Case Diagram yang diusulkan

Pada diagram di atas terdiri dari satu aktor dan bebrapa use case. Di dalam diagram ini terdapat sebuah extend yang digunakan untuk menunjukkan bahwa satu use case merupakan tambahan fungsional dari use case lain jika kondisi tertentu terpenuhi. Alur ini dimulai dari ketika pengguna memulai menjalankan program, dari informasi inilah akan diolah oleh aplikasi sehingga menampilkan visual sesuai dengan pilihan pada menu utama. Pengguna melakukan interaksi dengan memilih masing-masing gambar yang di inginkan, maka aplikasi akan secara otomatis memberikan output, contoh ketika pengguna menjalankan use case tentang aplikasi maka pengguna akan diarahkan ke layar tentang aplikasi.

\subsubsection{Activity Diagram}

\subsubsection{Activity Diagram Materi}

Activity Diagram Materi dari sistem yang akan dibuat, ditunjukan pada tabel 2.1.

Tabel 2.1 Activity Diagram Materi

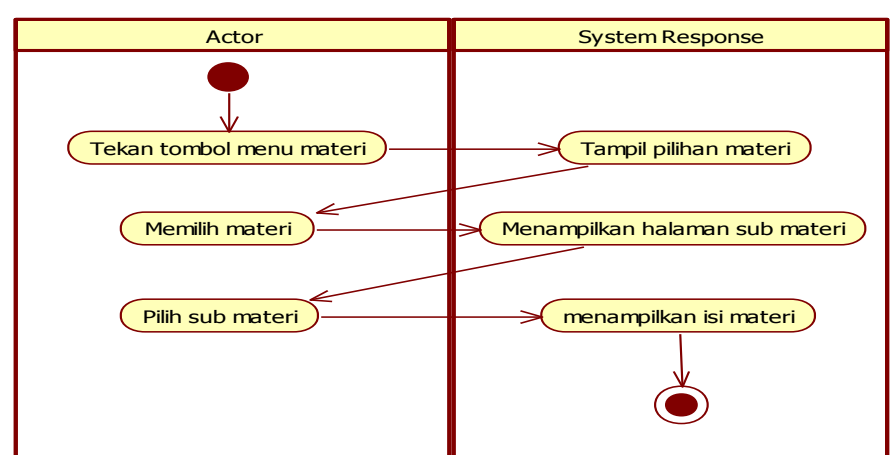

\subsubsection{Activity Diagram Latihan Soal}

Activity Diagram Kuis dari sistem yang akan dibuat, ditunjukan pada tabel 2.2.

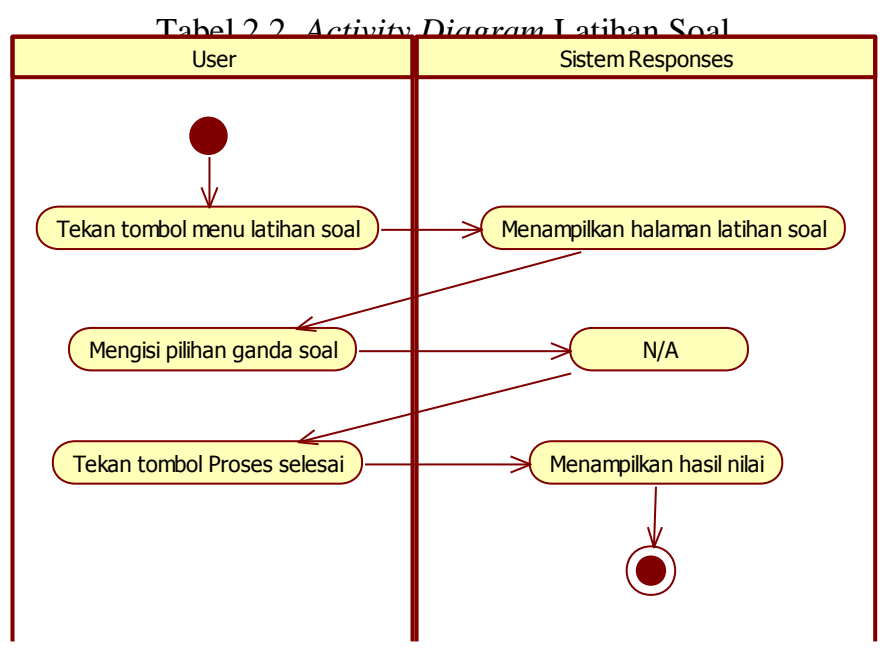

\subsubsection{Activity Diagram Bantuan}

Activity Diagram Bantuan dari sistem yang akan dibuat, ditunjukan pada tabel 2.3.

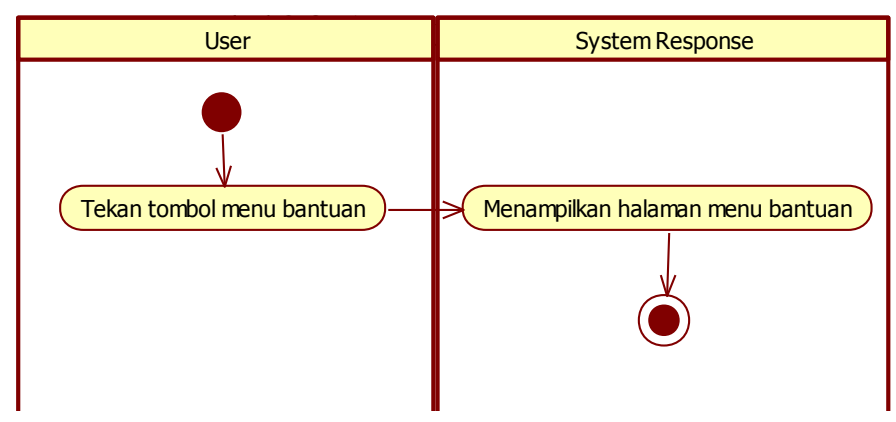

\subsubsection{Activity Diagram Tentang}

Activity Diagram Tentang dari sistem yang akan dibuat, ditunjukan pada tabel 2.4.

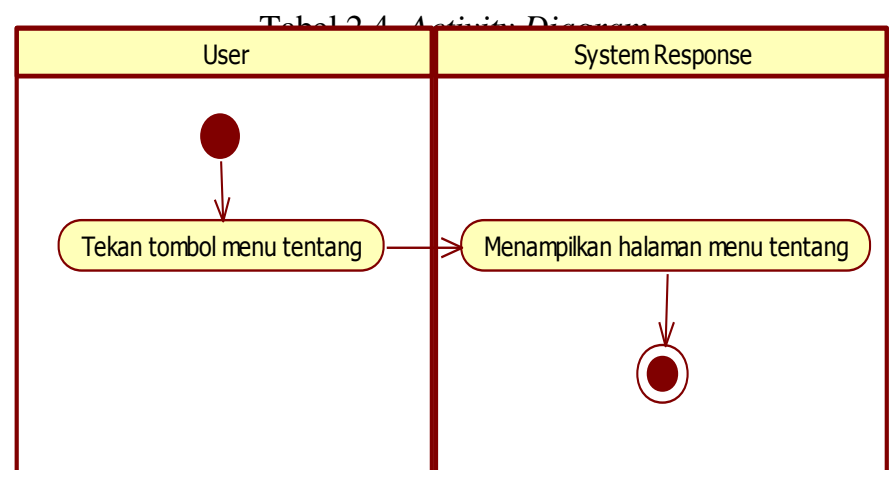




\subsubsection{Sequence Diagram}

Squence Diagram Menu Utama dari sistem yang akan dibuat, dapat dilihat pada gambar 2.3.

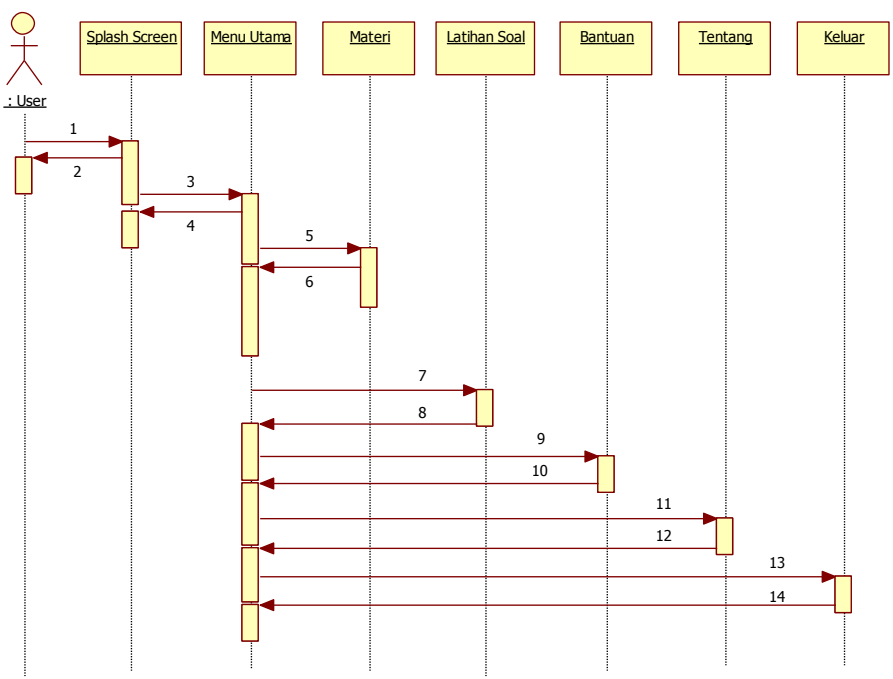

Gambar 3.3 Sequence Diagram Menu Utama

Keterangan :
1 : Memuat aplikasi

2 : Tampilan splash screen

3 : Masuk menu utama

4 : Tampilan menu utama

5 : Pilih menu materi

6 : Menu materi

7 : Pilih Latihan Soal
8 : Menu Latihan

9 : Pilih Bantuan

10 : Menu Bantuan

11 : Pilih Tentang

12 : Menu Tentang

13 : Pilih Keluar

14 : Menu Keluar

\subsection{Hasil}

\section{HASIL DAN PEMBAHASAN}

\subsubsection{Halaman Utama}

Pada halaman utama ini, ditampilkan sebuah desain yang menarik guna sebagai halaman pembuka dari aplikasi pembelajaran Matematika Kelas III SD berbasis android. Aplikasi melakukan proses loading untuk melanjutkan ke halaman selanjutnya. Tampilan halaman utama aplikasi dapat dilihat pada gambar 3.1.

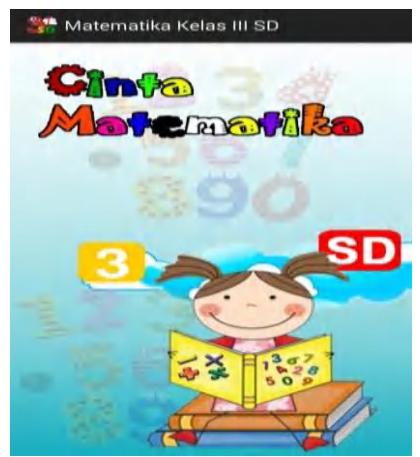

Gambar 3.1 Tampilan Halaman Utama Aplikasi

\subsubsection{Halaman Menu Utama}

Pada Menu utama terdiri dari beberapa button yaitu button Materi, button Latihan Soal, button Video Tutorial, button Tentang Aplikasi dan button Bantuan. Setiap button memiliki akses ke halaman sesuai dengan menu dan untuk mengaksesnya tentunya terlebih dahulu dibuatkan file class dari setiap Мепи. Tampilan halaman тепи utama aplikasi dapat dilihat pada gambar 3.2.

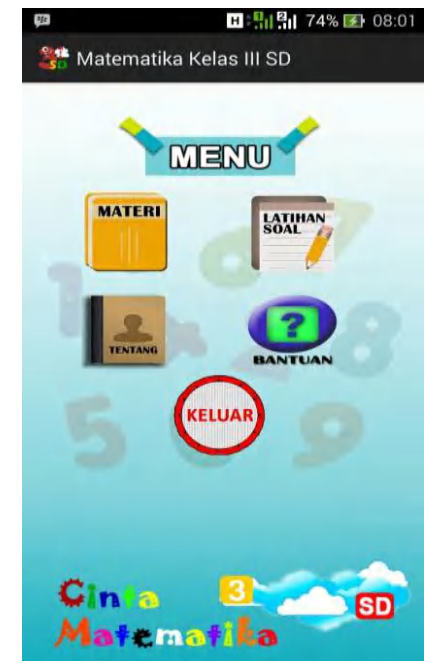

Gambar 3.2 Tampilan Menu Utama

\subsubsection{Halaman Menu Materi}

Меnu materi berisikan pokok pembahasan Matematika kelas III SD. Ada 4 pokok pembahasan yang jelaskan sesuai kurikulum pendidikan yaitu Bilangan, Pengukuran, Bilangan Pecahan dan Bangun Datar. Tampilan dari menu materi tersebut dibuat dalam bentuk list, dan pengguna dapat memilih materi apa yang ingin dipelajari. Tampilan halaman menu materi aplikasi dapat dilihat pada gambar 3.3.

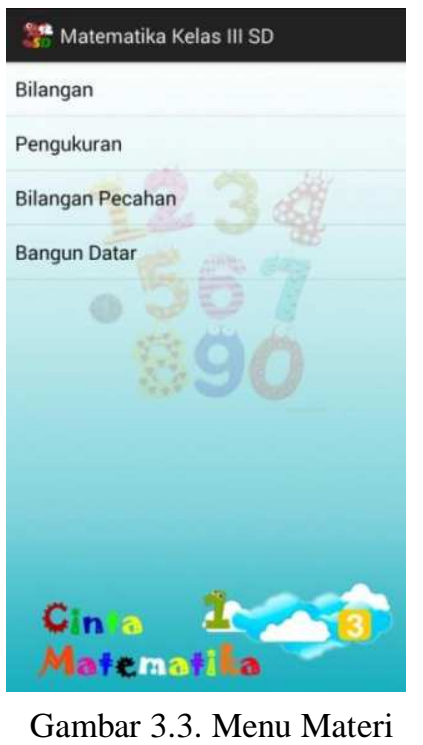

Pada Menu materi ini tidak menggunakan Android XML File, karena dalam pembuatan daftar materi hanya mengatur 
tampilan background yang akan digunakan dengan cara memanggil file image pada folder drawable pada project di Eclipse.

\subsubsection{Halaman Menu Latihan Soal}

Menu latihan soal berisikan latihan soal dari setiap pokok pembahasan Matematika kelas III SD. Ada 4 pokok pembahasan yang jelaskan sesuai kurikulum pendidikan yaitu Bilangan, Pengukuran, Bilangan Pecahan dan Bangun Datar. Setiap soal pada pokok pembahasan terdapat 10 soal dengan pilihan ganda. Tampilan menu latihan soal pada aplikasi dapat dilihat pada gambar 3.4.

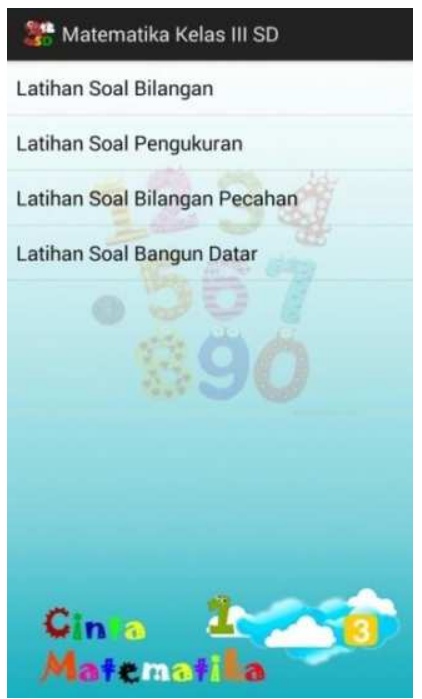

Gambar 3.4 Tampilan Daftar Menu Latihan Soal

Tampilan latihan soal bilangan pada aplikasi, dapat dilihat pada gambar 3.5.

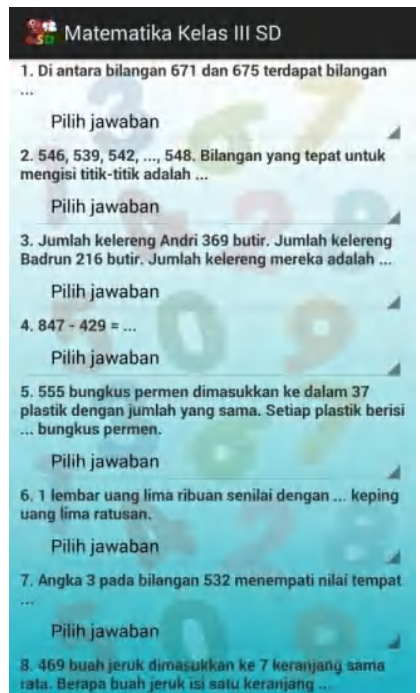

Gambar 3.5 Tampilan Latihan Soal Bilangan

Berikut adalah tampilan halaman hasil jawaban dari soal yang telah dijawab, dapat dilihat pada gambar 3.6.

\section{Sot Matematika Kelas III SD}

\section{HASIL}

Nilai anda adalah :

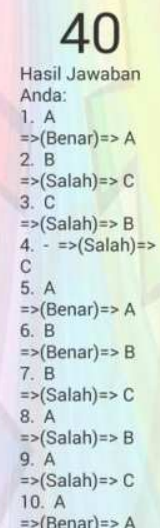

Gambar 3.6 Tampilan Halaman Hasil Jawaban dari Soal Yang Telah Dijawab

\subsubsection{Halaman Menu Tentang Aplikasi}

Menu Tentang Aplikasi dibuat guna menjelaskan kepada pengguna fungsi dari aplikasi ini dan mempublikasikasikan pembuat dari aplikasi pembelajaran Matematika Kelas III SD berbasis android. Tampilan menu tentang aplikasi dapat dilihat pada gambar 3.7.

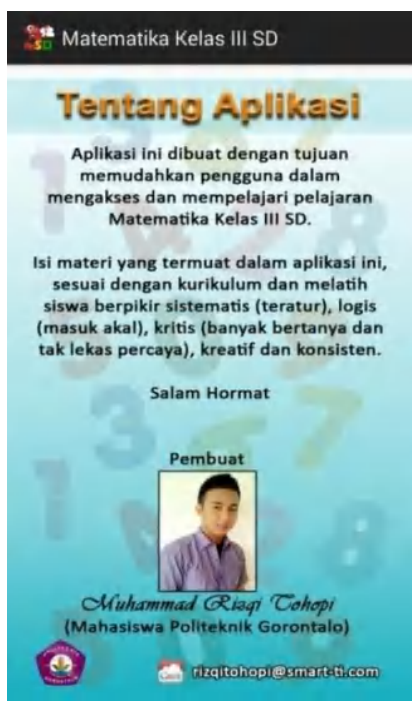

Gambar 3.7 Tampilan Halaman Menu Tentang Aplikasi

\subsubsection{Halaman Menu Bantuan}

Menu Bantuan dibuat guna menjelaskan kepada pengguna cara penggunaan dari aplikasi ini pembelajaran Matematika Kelas III SD berbasis android. Tampilan menu bantuan aplikasi dapat dilihat pada gambar 3.8.

Solt Matematika Kelas III SD 


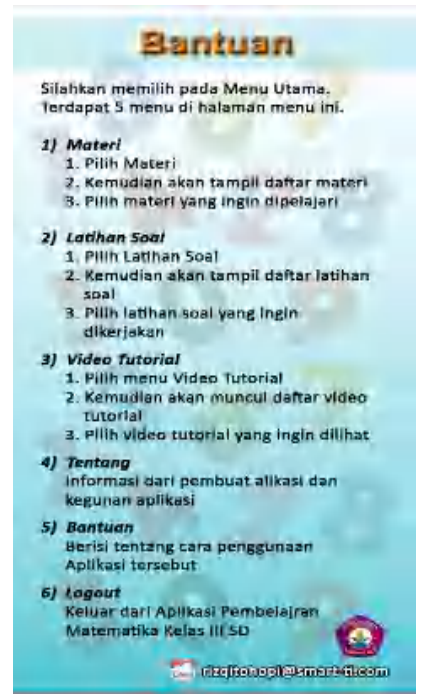

Gambar 3.8 Tampilan Halaman Menu Bantuan Aplikasi

\subsection{Pembahasan}

Dalam merancang sebuah aplikasi terdapat hal yang dibutuhkan untuk menunjang proses perancangannya yaitu: perangkat lunak dan perangkat keras.

\subsubsection{Spesifikasi Perangkat Keras}

Penerapan rancangan yang telah dijelaskan sebelumnya dibutuhkan beberapa perangkat keras untuk menyajikan aplikasi ini. Adapun alat-alat yang dibutuhkan adalah :

1. Smartphone Berbasiskan Sistem Operasi Android

Smartphone digunakan untuk menjalankan program aplikasi yang telah dikembangkan. Adapun smartphone yang digunakan adalah ASUS_T00F dengan spesifikasi sebagai berikut:

- Sistem Operasi : Android 4.4.2 "Gingerbread"

- Versi Kernel 3.10.20-262977-gdb13b6f

- Ruang Penyimpan : 8GB (internal) dan 8 GB (microSD)

2. Kabel data serial port

Fungsi dari kabel data ini adalah untuk menghubungkan antara Komputer dengan Smartphone.

3. Satu unit Laptop dengan spesifkasi antara lain:

- Prosesor : Intel® Core ${ }^{\mathrm{TM}} \mathrm{i} 3-2330 \mathrm{M} @ 2.20 \mathrm{GHz}$

- Memori : $4 \mathrm{~Gb}$

- Ruang Penyimpan : 500 GB

\subsubsection{Pemeliharaan Sistem}

Pemeliharaan sistem untuk aplikasi ini tergolong mudah, karena tidak perlu khawatir ada database yang hilang karena memang aplikasi ini tidak menggunakan database. Cara untuk memelihara sistem ini adalah dengan mem-backup file aplikasi ini disuatu tempat pada komputer atau hand phone milik user. Kemudian jangan lupa menginstall anti virus untuk mencegah komputer atau hand phone terkena virus yang bisa mengakibatkan aplikasi hilang atau terganggu sistem kerjanya.

\section{KESIMPULAN}

\subsection{Kesimpulan}

Berdasarkan pembahasan pada bab-bab sebelumnya, maka dapat ditarik kesimpulan yaitu aplikasi yang telah dibuat dapat menarik minat belajar anak terhadap pelajaran matematika khususnya kelas III SD yang berkaitan dengan materi bilangan, pengukuran, bilangan pecahan dan bangun datar dengan metode pembelajaran yang interaktif menggunakan media smartphone dalam pengawasan dan bimbingan orang tua.

\subsection{Saran}

Untuk peneliti aplikasi pembelajaran matematika kelas III SD berbasis android selanjutnya, diharapkan dapat menambahkan beberapa fitur yang menarik untuk aplikasi pembelajaran matematika kelas III SD ini sebagai berikut :

1. Pembuatan latihan soal pada aplikasi dibuat secara acak.

2. Aplikasi yang dikembangkan lebih lanjut diharapkan bisa diimplementasikan dalam aplikasi pembelajaran matematika untuk semua kelas di Sekolah Dasar dan aplikasi menggunakan client server. Sehingga data yang diakses lebih cepat dan proses update data mata pelajaran lebih maksimal.

\section{DAFTAR PUSTAKA}

[1] Departemen Pendidikan Nasional (2011). KAMUS BESAR BAHASA INDONESIA PUSAT BAHASA EDISI KEEMPAT. Jakarta : PT. Gramedia Pustaka Utama.

[2] Kadir, Abdul (2014). Buku Pertama Belajar Pemrograman Java untuk Pemula. Yogyakarta : Mediakom.

[3] Sugiarti, ST, M.Kom, Yuni (2013). Analisis \& Perancangan UML. Yogyakarta : GRAHA ILMU,

[4] Supardi, Ir. Yuniar (2014). Sетиa Bisa Menjadi Programmer Android Case Study. Jakarta : PT. Alex Media Komputindo.

[5] Suprianto, Dodit, dan Agustina, S.Kom, M.Pd, Rini (2012). PEMROGRAMAN APLIKASI ANDROID. Yogyakarta : Mediakom.

[6] Undang-undang RI No. 20 Tahun 2003 Tentang Sistem Pendidikan Nasional. 